\title{
Biomotor Analysis of Speed and Flexibility in the Karate Talented Athletes Coaching in the Special Region of Yogyakarta
}

\author{
Widha Srianto $^{1, *}$, Siswantoyo Siswantoyo ${ }^{1}$ \\ ${ }^{1}$ Faculty of Sport Sciences, Universitas Negeri Yogyakarta, Yogyakarta, Indonesia \\ *Corresponding author.Email: widhasrianto.2021@student.uny.ac.id
}

\begin{abstract}
Biomotor speed and flexibility are important components that must be possessed by a karate athlete. This study aims to analyze the biomotor abilities of speed and flexibility in karate talented athletes in the Special Region of Yogyakarta. The research sample consisted of 20 karate athletes who participated in the talented athlete coaching program in the Special Region of Yogyakarta. The research was conducted in a quantitative descriptive. The data was obtained by using the 50-meter sprint test to determine the speed of the athletes and the sit and reach test to determine their flexibility. The research data were then analyzed and categorized using test norms so that the category of each athlete could be identified. The conclusion obtained from this study is that the speed biomotor component in the karate gifted athlete coaching program is classified into 3 categories: 2 athletes with a percentage of $10 \%$ are in a perfect category, 15 athletes with a percentage of $75 \%$ are in the excellent category, and 3 athletes with a percentage of $15 \%$ are included in the good category. For biomotor flexibility, the research results are classified into 2 categories, namely: 16 athletes with a percentage of $80 \%$ are in a perfect category while 4 athletes with a percentage of $20 \%$ are in the excellent category.
\end{abstract}

Keywords: Biomotor, Football

\section{INTRODUCTION}

Karate is one of the most popular sports [1][2] with developments that are currently growing rapidly. This happens because of the dominance of the involvement of children and adolescents in participating in karate sports activities [3]. Karate sports in the Special Region of Yogyakarta has a tiered talent development program that operates under the coordination of the Youth and Sports Center in collaboration with the Yogyakarta Special Region Karate Sports Federation as the parent of the karate organization [4]. Karate has tiered official events, such as the National Student Sports Competition (KOSN) and Student Sports Week (POPNAS) where participants in these activities are elementary, junior high, and high school students [5]

The guidance provided, one of which aims to improve the quality of training related to technical maturation, adding techniques, to improving techniques or movements [6]. Physical exercise can improve biomotor abilities [7]. Biomotor ability in this case is an important component to support athlete movement so that it can support athlete achievement [8]. The biomotor components consist of strength, endurance, explosive power, speed, flexibility, agility, accuracy, reaction, balance, and coordination [9]. In karate, the biomotor components of speed and flexibility play a very important role because they support the development of an athlete [10]. It is also mentioned in several studies that speed biomotor also has an important role in other sports such as taekwondo [11] and silat [12]. The importance of biomotor flexibility is also found in judo [13] and taekwondo[14]. Based on several references described, it can be seen that speed and flexibility are very important biomotor components. This study, therefore, aims to analyze the biomotor abilities of speed and flexibility possessed by talented junior karate athletes in the Special Region of Yogyakarta.

\section{METHODS}

This research was conducted in a quantitative descriptive manner. This type of research is a test whose hypothesis is not the main purpose, but rather to explain the condition of the existing variables [15]. Data collection in this study was carried out through tests. The test is a way to conduct an assessment in the form of a task or a series of tasks that must be done by athletes to know the abilities possessed or achieved by 
athletes [16]. The research sample was 20 junior karate athletes who participated in the talented athlete coaching program in the Special Region of Yogyakarta. The instrument used in this study for the speed test was a 50-meter sprint, while for the flexibility test, sit and reach were used. Speed measurement using the 50-meter sprint test aims to measure the athlete's speed. This test begins with a standing start where 2 athletes must stand behind the starting line. After there is a "yes" signal, the athlete must run as fast as possible towards the finish line. The score in this case is determined based on the time obtained. This test consisted of 2 trials where the best score was selected and then included in the scoring norm [17]. Flexibility was measured using the sit and reach test which aims to measure the flexibility of the lower back and hamstrings. The tool used in this test is a bench sit and reach equipped with a ruler/scale. The execution procedure begins with the athlete being instructed to sit with straight legs barefoot and feet together. The athlete is then instructed to bend as much as she/he could so that both fingers slide over the line of the scale. If the tool has a chamber length of $15 \mathrm{~cm}$, then the distance reached by the tip of the middle finger needs to be added to the length of the chamber. This test was carried out 3 times in which the best score was selected and listed in the scoring norm [18]. The speed and flexibility test will then be continued with the data collection stage to find the percentage. The results of this stage are as follows: [F1]

\section{Number of subjects in the category Total subjects}

\section{RESULTS}

Data related to the results of speed and flexibility tests carried out on talented junior karate athletes from the Special Region of Yogyakarta using the 50-meter running speed test and sit and reach flexibility test are presented in the following table.

Tabel 1. Results of the 50-meter sprint test for talented junior karate athletes in the Special Region of Yogyakarta.

\begin{tabular}{|l|l|l|l|}
\hline Score & Category & Frequency & Percentage \% \\
\hline 5 & Perfect & 2 & 10 \\
\hline 4 & Excellent & 15 & 75 \\
\hline 3 & Good & 3 & 15 \\
\hline 2 & Enough & 0 & 0 \\
\hline 1 & Poor & 0 & 0 \\
\hline Total & & 20 & 100 \\
\hline
\end{tabular}

Tabel 2. Norms of the 50-meter sprint test [17].

\begin{tabular}{|l|l|lll|lll|}
\hline Score & Category & Male & & \multicolumn{2}{|l|}{ Female } & \\
\hline 5 & Perfect & s/d & - & 6.7 & s/d & - & 7.2 \\
\hline
\end{tabular}

\begin{tabular}{|c|c|c|c|}
\hline & & seconds & seconds \\
\hline 4 & Excellent & $\begin{array}{l}6.8 \quad- \\
\text { seconds }\end{array}$ & $\begin{array}{ll}7.3- & 8.3 \\
\text { seconds } & \\
\end{array}$ \\
\hline 3 & Good & $\begin{array}{ll}7.7 \quad- & 8.7 \\
\text { seconds } & \end{array}$ & $\begin{array}{lr}8.4 \quad- & 9.6 \\
\text { seconds } & \\
\end{array}$ \\
\hline 2 & Enough & $\begin{array}{lll}8.8 \quad- & 10.3 \\
\text { seconds } & \\
\end{array}$ & $\begin{array}{lrr}.7 & - & 11.0 \\
\text { seconds } & \end{array}$ \\
\hline 1 & Poor & $10.4-$ etc & 11.1 - etc \\
\hline
\end{tabular}

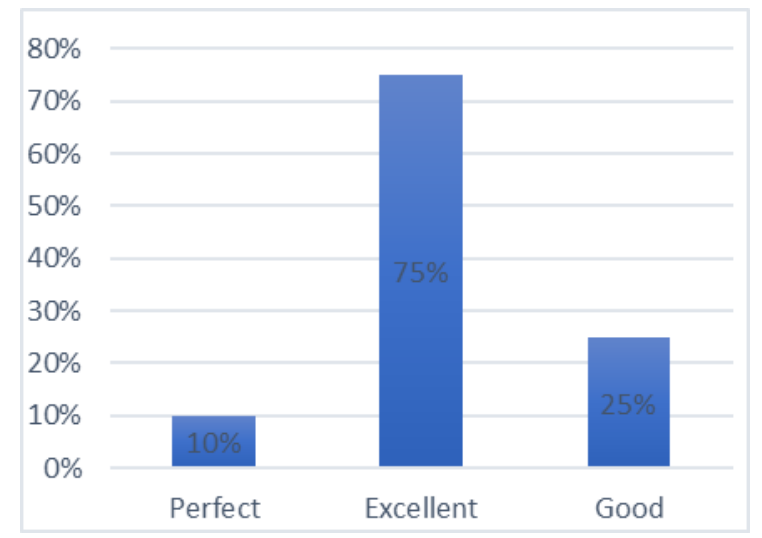

Figure 1. Diagram of the percentage of the 50-meter sprint test results for talented karate athletes in the Special Region of Yogyakarta.

Meanwhile, data on flexibility tests using sit and reach tests on junior karate talented athletes in the Special Region of Yogyakarta are as follows:

Table 3. Sit and reach test results for junior karate talented athletes in the Special Region of Yogyakarta

\begin{tabular}{|l|l|l|l|}
\hline Score & Category & Frequency & Percentage \% \\
\hline 5 & Perfect & 16 & 80 \\
\hline 4 & Excellent & 4 & 20 \\
\hline 3 & Good & 0 & 0 \\
\hline 2 & Enough & 0 & 0 \\
\hline 1 & Poor & 0 & 0 \\
\hline Total & & 20 & 100 \\
\hline
\end{tabular}

Table 4. Sit and reach test norms [18]

\begin{tabular}{|l|l|l|l|}
\hline Score & Category & Male & Female \\
\hline 5 & Perfect & $>14$ & $>15$ \\
\hline 4 & Excellent & $11-14$ & $12-15$ \\
\hline 3 & Good & $7-10$ & $7-11$ \\
\hline 2 & Enough & $4-6$ & $4-6$ \\
\hline 1 & Poor & $<4$ & $<4$ \\
\hline
\end{tabular}




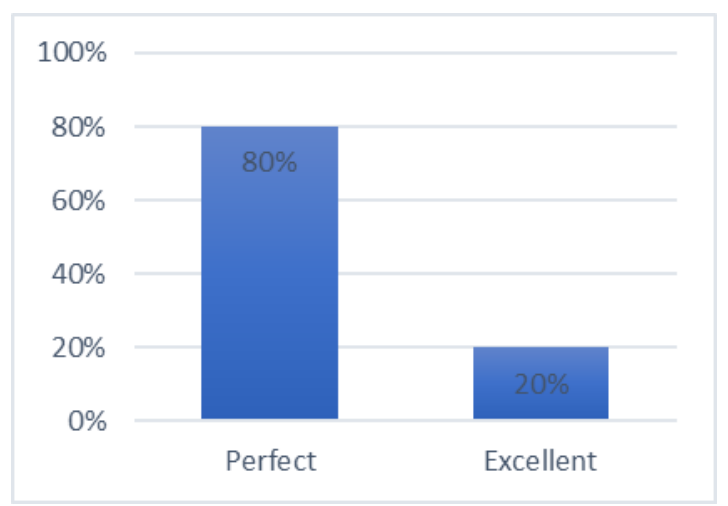

Figure 2. Sit and reach percentage diagram of talented karate athletes in the Special Region of Yogyakarta

\section{DISCUSION}

This study aims to analyze the condition of the biomotor speed and flexibility of talented junior karate athletes in the Special Region of Yogyakarta. Speed is a short movement after being stimulated or can be defined as the ability to move quickly forward, sideways, backward, and various angles [19]. Flexibility is a person's ability to move joints optimally which is determined by joint structure, ligament conditions, and muscle ability [20]. Speed is the time that can be achieved with a short duration. The athlete's performance in this case is very dependent on the speed he has [21][22]. The very high correlation coefficient proves that the speed of the stroke is strongly influenced by the maximum pressure on the foot [23]. Flexibility in karate is very important to produce maximum technique. Sports that use techniques with a wide range and produce maximum speed [10] for example is karate where flexibility is needed to encourage the superior joint ability to produce maximum kicks. [20]

Biomotor speed and flexibility are essential components in karate. In a competition, speed and flexibility have an important role to get effective movement in athletes [24]. From the results of measurements made on the 50-meter sprint test, it was found that athletes were divided into 3 categories, consisting of perfect, excellent, and good. Athletes in the perfect category consist of 2 athletes (10\%). Athletes in the excellent category were 15 athletes $(75 \%)$ and athletes in the good category were 3 athletes $(15 \%)$. The sit and reach test produced athletes who were divided into 2 categories, namely perfect with 16 athletes $(80 \%)$ and excellent with 4 athletes $(20 \%)$.

\section{CONCLUSION}

Based on the research results, it can be concluded that speed biomotor and flexibility is important and must be owned by a Karate athlete to support physical and technical ability. The research data showed that speed biomotor ability owned by talented junior karate athlete in average is at excellent, while the average flexibility biomotor component owned by talended athlete is in perfect category. Therefore, it can be concluded that a talented karate athlete has average speed biomotor ability and flexibility in Perfect and excellent category.

\section{REFERENCES}

[1] H. Chaabene et al., "Criterion related validity of karate specific aerobic test (KSAT)," Asian J. Sports Med., vol. 6, no. 3, 2015, doi: 10.5812/asjsm.23807.

[2] N. Koropanovski et al., "Anthropometric and physical performance profiles of elite karate kumite and kata competitors," J. Hum. Kinet., vol. 30, no. 1, pp. 107-114, 2011, doi: 10.2478/v10078-011-0078-x.

[3] Y. Yabe et al., "Low back pain in school-aged martial arts athletes in Japan: A comparison among Judo, Kendo, and Karate," Tohoku J. Exp. Med., vol. 251, no. 4, pp. 295-301, 2020, doi: 10.1620/tjem.251.295.

[4] A. Nugroho, "Seleksi Atlet Pelajar DIY Digelar," www.tribunjogja.com, 2018. https://jogja.tribunnews.com/2018/02/24/seleksi-atlet-pelajardiy-digelar (accessed Sep. 23, 2021).

[5] Kompas.com, "Kompetisi Olahraga Siswa Nasional 2021 Resmi Dibuka, Lomba Daring Sebab Masih Pandemi," www.kompas.com, 2021. https://jurnalsoreang.pikiranrakyat.com/olahraga/pr-1012662870/kompetisi-olahragasiswa-nasional-2021-resmi-dibuka-lomba-daring-sebabmasih-pandemi (accessed Sep. 30, 2021).

[6] A. Sulistiyo and S. Rahayu, "Evaluasi Program Pemusatan Latihan Cabang Olahraga Senam Kabupaten Pati Persiapan Kejuaraan Provinsi Jawa Tengah Abstrak," J. Phys. Educ. Sport., vol. 6, no. 3, pp. 232-235, 2017.

[7] I. Ferdiana, M. Muhammad, and O. Wiriawan, "Effect of Exercise Countermovement Jump and Depth Jump against the Increase Agility and Leg Muscle Power," Budapest Int. Res. Critics Linguist. Educ. J., vol. 3, no. 4, pp. 2259-2273, 2020, doi: 10.33258/birle.v3i4.1509.

[8] I. J. Kusuma, P. J. Nurcahyo, and G. N. Alivian, "Komponen Biomotor Dominan Pada Permainan Tradisonal Dul-Dulan Khas Banyumas," Phys. Act. J., vol. 1, no. 1, p. 44, 2019, doi: 10.20884/1.paju.2019.1.1.2000.

[9] I. G. P. N. A. Santika, "Pengukuran Komponen Biomotor Mahasiswa Male Semester V Kelas A Fakultas Pendidikan Olahraga dan Kesehatan IKIP PGRI Bali Tahun 2017," J. Pendidik. Kesehat. Rekreasi, vol. 1, pp. 85-92, 2017.

[10] J. Jukić, R. Katić, and S. Blažević, "Impact of morphological and motor dimensions on success of young male and female karateka," Coll. Antropol., vol. 36, no. 4, pp. 1247-1255, 2012.

[11] B. O. Chun, S. H. Choi, J. B. Lee, E. Kim, and K. Lee, "Effects of core balance and plyometric training on anaerobic power and dynamic postural stability in youth taekwondo athletes," Exerc. Sci., vol. 30, no. 2, pp. 167-174, 2021, doi: 10.15857/KSEP.2021.30.2.167.

[12] N. Ihsan, Y. Yulkifli, and Y. Yohandri, "Instrumen Kecepatan Tendangan Pencak Silat Berbasis Teknologi," J. 
Sosioteknologi, vol. 17, no. 1, pp. 124-131, 2018, doi: 10.5614/sostek.itbj.2018.17.1.12.

[13] A. R. Saraiva, V. M. Reis, P. B. Costa, C. M. Bentes, G. V. Costae Silva, and J. S. Novaes, "Chronic Effects of different resistance training exercise orders on flexibility in elite judo athletes," J. Hum. Kinet., vol. 40, no. 1, pp. 129-137, 2014, doi: 10.2478/hukin-2014-0015.

[14] Andres Saes Abello, Guillermo, Belen Carrillo Cardenas, Pedro Arias, A. GaviriaManuel, and K. Alexander, "Some Features of Increasing Special Flexibility in Taekwondo," Sport. Bull. Dnieper, vol. 1, pp. 191-196, 2020, doi: 10.32540/2071-1476-2019-1-191.

[15] S. Arikunto, Prosedur Penelitian: Suatu Pendekatan Praktik. Jakarta: Rineka Cipta, 2011.

[16] O. Wiriawan, Panduan Pelaksanaan Tes \& Pengukuran Olahragawan, 1st ed. Yogyakarta: Thema Publishing, 2017.

[17] E. Sepdanius, M. S. Rifki, and A. Komaini, Tes dan Pengukuran Olahraga, 1st ed. Depok: PT RajaGrafindo Persada, 2019.

[18] A. M. N. Pasaribu, Tes dan Pengukuran Olahraga. Banten: Yayasan Pendidikan dan Sosial Indonesia Maju, 2020.

[19] P. Collins, Speed for Sport. Germany: B.O.S.S Druck und Medien GmbH, 2009.
[20] D. Hoelbling, M. Grafinger, M. M. Smiech, D. Cizmic, P. Dabnichki, and A. Baca, "Acute response on general and sport specific hip joint flexibility to training with novel sport device," Sport. Biomech., vol. 00, no. 00, pp. 1-16, 2021, doi: 10.1080/14763141.2021.1922742.

[21] R. Katić, J. Jukić, and M. Milić, "Biomotor status and kinesiological education of students aged 13 to 15 years Example: Karate," Coll. Antropol., vol. 36, no. 2, pp. 555562, 2012.

[22] P. Przybylski, A. Janiak, P. Szewczyk, D. Wieliński, and K. Domaszewska, "Morphological and motor fitness determinants of shotokan karate performance," Int. J. Environ. Res. Public Health, vol. 18, no. 9, 2021, doi: 10.3390/ijerph18094423.

[23] T. M. Daniel and P. Răzvan-Liviu, "Correlation between Plantar Pressure and Striking Speed in Karate-do,” Procedia Soc. Behav. Sci., vol. 117, pp. 357-360, 2014, doi: 10.1016/j.sbspro.2014.02.227.

[24] X. Li, G. Zhang, C. Zhou, and X. Wang, "Negative emotional state slows down movement speed: Behavioral and neural evidence," PeerJ, vol. 2019, no. 9, pp. 1-21, 2019, doi: $10.7717 /$ peerj. 7591 